\title{
Case Definition of Chronic Pulmonary Aspergillosis in Resource-Constrained Settings
}

\author{
David W. Denning, lain D. Page, Jeremiah Chakaya, Kauser Jabeen, Cecilia M. Jude, \\ Muriel Cornet, Ana Alastruey-Izquierdo, Felix Bongomin, Paul Bowyer, Arunaloke Chakrabarti, \\ Sara Gago, John Guto, Bruno Hochhegger, Martin Hoenigl, Muhammad Irfan, Nicholas Irurhe, \\ Koichi Izumikawa, Bruce Kirenga, Veronica Manduku, Samihah Moazam, Rita O. Oladele, \\ Malcolm D. Richardson, Juan Luis Rodriguez Tudela, Anna Rozaliyani, Helmut J.F. Salzer, \\ Richard Sawyer, Nasilele F. Simukulwa, Alena Skrahina, Charlotte Sriruttan, \\ Findra Setianingrum, Bayu A.P. Wilopo, Donald C. Cole, Haileyesus Getahun
}

Author affiliations: University of Manchester, Manchester, UK (D.W. Denning, I.D. Page, F. Bongomin, P. Bowyer, S. Gago, R.O. Oladele, C. Sriruttan, F. Setianingrum, B.A.P. Wilopo); Wythenshawe Hospital Manchester University NHS Foundation Trust, Manchester (D.W. Denning, I.D. Page, S. Moazam, M.D. Richardson, R. Sawyer); The Global Action Fund for Fungal Infections, Geneva, Switzerland (D.W. Denning, J. Guto, J.L. Rodriguez Tudela); Kenya Medical Research Institute, Nairobi, Kenya (J. Chakaya, V. Manduku); Aga Khan University, Karachi, Pakistan (K. Jabeen, M. Irfan); Olive View-UCLA Medical Center, Sylmar, California, USA (C.M. Jude); Centre Hospitalier Universitaire Grenoble Alpes, Grenoble, France (M. Cornet); Instituto de Salud Carlos III, Madrid, Spain (A. Alastruey-Izquierdo); Postgraduate Institute of Medical Education and Research, Chandigarh, India (A. Chakrabarti); Federal University of Health Sciences of Porto Alegre, Porto Alegre, Brazil (B. Hochhegger); University of California San Diego, San Diego, California, USA (M. Hoenigl); Medical University of Graz, Graz, Austria (M. Hoenigl); Center for Biomarker Research in Medicine, Graz (M. Hoenigl); Lagos University Teaching Hospital, Lagos, Nigeria (N. Irurhe); Nagasaki University Graduate School of Biomedical Sciences, Nagasaki, Japan (K. Izumikawa); Mulago Hospital and Makerere University, Kampala, Uganda (B. Kirenga); University of Lagos, Lagos (R.O. Oladele); Universitas Indonesia, Jakarta, Indonesia (A. Rozaliyani, F. Setianingrum); Research Center Borstel, Borstel, Germany (H.J.F. Salzer); Royal Liverpool University Hospital, Liverpool, UK (N.F. Simukulwa); The Republican Scientific and Practical Centre for Pulmonology and TB, Minsk, Belarus (A. Skrahina, C. Sriruttan); National Institute for Communicable Diseases, Johannesburg, South Africa (C. Sriruttan); University of the Witwatersrand, Johannesburg (C. Sriruttan); Universitas Padjadjaran, Bandung, Indonesia (B.A.P. Wilopo); University of Toronto, Toronto, Ontario, Canada (D.C. Cole); World Health Organization, Geneva (H. Getahun)

DOI: https://doi.org/10.3201/eid2408.171312
Chronic pulmonary aspergillosis (CPA) is a recognized complication of pulmonary tuberculosis (TB). In 2015, the World Health Organization reported 2.2 million new cases of nonbacteriologically confirmed pulmonary TB; some of these patients probably had undiagnosed CPA. In October 2016, the Global Action Fund for Fungal Infections convened an international expert panel to develop a case definition of CPA for resource-constrained settings. This panel defined CPA as illness for $\geq 3$ months and all of the following: 1) weight loss, persistent cough, and/or hemoptysis; 2) chest images showing progressive cavitary infiltrates and/or a fungal ball and/or pericavitary fibrosis or infiltrates or pleural thickening; and 3) a positive Aspergillus IgG assay result or other evidence of Aspergillus infection. The proposed definition will facilitate advancements in research, practice, and policy in lower- and middle-income countries as well as in resource-constrained settings.

The differential diagnosis for pulmonary tuberculosis 1 (TB) is wide and includes nontuberculous mycobacteria (NTM) infection, endemic fungal infections such as coccidioidomycosis and histoplasmosis, allergic bronchopulmonary aspergillosis, and chronic pulmonary aspergillosis (CPA) (1-7). Sequelae of pulmonary TB, such as bronchiectasis and restricted lung capacity, can mimic infection relapse $(8-10)$. Accurate diagnosis is essential for adequate treatment.

The 2015 World Health Organization annual report notes that $\approx 2.2$ million $(\approx 43 \%$ ) of 5.2 million cases of incident pulmonary TB were clinically diagnosed or smearnegative (11). Only $21 \%-40 \%$ of smear-negative pulmonary TB cases are culture positive $(12,13)$. Exclusion of alternatives is challenging in many lower- and middle-income countries (14). The World Health Organization report comments, "Most clinical features of TB and abnormalities on X-ray or histology results generally associated with TB have low specificity, which may lead to false diagnoses of $\mathrm{TB}$, and hence to people being enrolled on TB treatment unnecessarily" (11). 
Although coccidioidomycosis, histoplasmosis, and paracoccidioidomycosis are regionally confined, aspergillosis is global. Each year, an estimated 373,000 new CPA cases complicate treated pulmonary TB within 12 months of completion of anti-TB therapy; the 5-year period prevalence is $1,174,000$ (range $397,000-2,088,000$ ) cases (9). This wide range results from several factors, notably the extrapolation of CPA diagnosis from a limited UK dataset of only 544 patients with pulmonary cavities (15), substantial variability in the published frequency of cavitation after treatment of pulmonary TB, absence of an estimate of CPA prevalence among patients without cavities, and lack of knowledge of the effects of concurrent HIV infection. The incidence and prevalence of CPA are not known but are probably underestimated, in part because CPA occurs in patients with active pulmonary $\mathrm{TB}$, as a sequela of prior pulmonary TB (16), or as a complication of other pulmonary disorders with symptoms similar to those of pulmonary $\mathrm{TB}$, and is incorrectly diagnosed and treated as pulmonary TB (17).

Diagnostic guidelines for CPA have recently been published in English and Japanese, emphasizing the central role of advanced imaging and serologic testing for Aspergillus (18-20). Unfortunately, these diagnostics are infrequently available in many resource-constrained settings. In October 2016, the Global Action Fund for Fungal Infections convened an international panel to develop an operational definition of CPA for research and clinical care in resourceconstrained settings. The panel's goals were to adapt the existing European Society for Clinical Microbiology and Infectious Diseases and European Respiratory Society (19) and Infectious Diseases Society of America guideline case definitions of CPA (18) to promote research so that critical data will be available to inform policy and practice, including surveillance, and to enable individualized clinical care for optimal patient management.

\section{Methods}

\section{Literature and Existing Guidelines}

We built on the work of 2 recent CPA expert panels (1820). These panels undertook comprehensive searching, appraisal, and synthesis of the relevant literature, including diagnosis and case definitions. We included these papers in a package of materials relevant to diagnosis in different clinical contexts (i.e., underlying disease in patients in whom CPA is developing, CPA and clinically diagnosed pulmonary $\mathrm{TB}$, radiologic assessment and characteristics of CPA, and comparisons of laboratory diagnosis with different immunoassays).

\section{Workshop Participants}

The Global Action Fund for Fungal Infections (https://www.gaffi.org) invited 36 experts from all regions of the world, according to expertise. The experts had already implemented CPA diagnostic capacity or were in the process of doing so. Participants also included experts from lower- and middle-income countries that had active clinical and public health programs focused on respiratory diseases including TB. Clinical expertise included internal medicine, pulmonary disease, infectious disease, critical care, thoracic radiology, medical microbiology, and medical mycology, as well as various health system organizational roles and levels (e.g., secondary care consultants, national reference laboratories, national research centers, and international health organizations). Of the 36 invited experts, 33 (the authors) attended a workshop in Liverpool, UK.

\section{Operational Definitions Indicator Selection}

Morning presentations and discussions built on prior reading material and provided all participants evidence of CPA burden, risk factors, clinical presentations, diagnostic tools, treatment options, recurrences, and prior case definitions. Three facilitated afternoon breakout groups started with CPA diagnostic indicator types (i.e., clinical presentation, radiology, medical microbiology-mycology-immunology) and discussed options for diagnosis, focusing on secondary care levels and above for lower- and middle-income countries. A recorder took notes, and the pros and cons of different indicators were shared in a plenary session. Subsequently, 3 cross-indicator groups worked to bring the indicators together, constructing key criteria for CPA with different clinical or radiologic presentations.

\section{Development of Case Definitions}

Plenary discussion participants compared and contrasted the different approaches and moved toward operational definitions. On the basis of consolidated notes from breakout groups and plenary sessions, descriptions of possible, probable, and confirmed CPA were synthesized to garner consensus on the most critical elements of the diagnosis. Simple graphic representations were developed, shared with breakout group leaders for feedback, and subsequently revised through iteration. Further iteration on the key elements of the algorithms to be used in the field and minimal definitional requirements were conducted via email and online file-sharing services, simplifying the definition to a single, composite definition and algorithm.

\section{Results}

Modern diagnostic criteria for CPA date from 2003 (21) and have been used in some prospective clinical trials (Table 1) and refined for specific purposes. The consensus group considered diagnostic criteria in 3 sections: clinical features, radiologic criteria, and microbiological criteria. 
Table 1. Published diagnostic features and criteria for chronic pulmonary aspergillosis*

\begin{tabular}{|c|c|c|c|c|c|c|}
\hline \multirow[b]{2}{*}{ Parameter } & \multicolumn{6}{|c|}{ Reference } \\
\hline & $(21)$ & $(22)$ & $(23)$ & $(24) \dagger$ & $(25)$ & $(19)$ \\
\hline Symptoms & $\begin{array}{l}\geq 1 \text { of the following } \\
\text { for } 3 \text { mo: WL, } \\
\text { productive cough, } \\
\text { hemoptysis plus } \\
\text { absence of overt } \\
\text { immunosuppression }\end{array}$ & $\begin{array}{c}\geq 1 \text { of the } \\
\text { following (no } \\
\text { duration } \\
\text { specified): fever, } \\
\text { WL, sputum } \\
\text { production, } \\
\text { cough, } \\
\text { hemoptysis, } \\
\text { fatigue, } \\
\text { shortness of } \\
\text { breath }\end{array}$ & $\begin{array}{l}\text { Performance } \\
\text { status } 1-2\end{array}$ & $\begin{array}{l}\text { All of the } \\
\text { following } \\
\text { required for 1-6 } \\
\text { mo: fever, } \\
\text { cough, sputum } \\
\text { production, } \\
\text { weight loss }\end{array}$ & $\begin{array}{l}\geq 1 \text { of the following } \\
\text { for } 3 \text { mo: weight } \\
\text { loss, productive } \\
\text { cough, hemoptysis } \\
\text { plus absence of } \\
\text { overt } \\
\text { immunosuppression }\end{array}$ & $\begin{array}{l}\text { "Significant pulmonary } \\
\text { and/or systemic } \\
\text { symptoms for } 3 \\
\text { months or more"; no } \\
\text { specific symptoms } \\
\text { listed }\end{array}$ \\
\hline Radiology & $\begin{array}{l}\geq 1 \text { of the following: } \\
\text { cavitary lesion with } \\
\text { paracavitary } \\
\text { fibrosis, new or } \\
\text { expanding cavity on } \\
\text { serial imaging }\end{array}$ & $\begin{array}{l}\geq 1 \text { of the } \\
\text { following: new } \\
\text { infiltrates, cavity } \\
\text { formation, } \\
\text { expansion of } \\
\text { preexisting } \\
\text { cavities; with or } \\
\text { without the } \\
\text { following: } \\
\text { pericavitary } \\
\text { infiltrates, } \\
\text { adjacent pleural } \\
\text { thickening }\end{array}$ & $\begin{array}{l}\text { Compatible } \\
\text { chest CT scan } \\
\text { or photo- } \\
\text { graphically } \\
\text { confirmed } \\
\text { endoscopic } \\
\text { lesion }\end{array}$ & $\begin{array}{c}\text { Cavitary } \\
\text { pulmonary } \\
\text { lesion with } \\
\text { evidence of } \\
\text { pericavitary } \\
\text { infiltrates and } \\
\text { adjacent pleural } \\
\text { thickening } \\
\text { with/without } \\
\text { fungal ball }\end{array}$ & $\begin{array}{l}\geq 1 \text { of the following: } \\
\text { cavitary lesion with } \\
\text { paracavitary } \\
\text { fibrosis, new or } \\
\text { expanding cavity on } \\
\text { serial imaging }\end{array}$ & $\begin{array}{c}\text { Both required: } \geq 1 \\
\text { pulmonary cavities } \\
\text { with either thick or thin } \\
\text { wall, possibly } \\
\text { containing } \\
\text { aspergilloma or } \\
\text { irregular intraluminal } \\
\text { material; overt } \\
\text { radiologic progression } \\
\text { over } \geq 3 \text { mo required } \\
\text { (new cavities, } \\
\text { increasing pericavitary } \\
\text { infiltrates, or } \\
\text { increasing fibrosis) }\end{array}$ \\
\hline $\begin{array}{l}\text { Aspergillus } \\
\text { antibody/ } \\
\text { culture }\end{array}$ & $\begin{array}{l}\text { Either positive } \\
\text { precipitins, or, } \\
\text { culture from } \\
\text { pulmonary or } \\
\text { pleural cavity }\end{array}$ & $\begin{array}{c}\geq 1 \text { of the } \\
\text { following: } \\
\text { platelia serum } \\
\text { galactomannan } \\
\text { index }>1.0, \\
\text { positive } \\
\text { precipitins, } \\
\text { positive }(1,3)-\beta- \\
\text { D-glucan, } \\
\text { evidence of } \\
\text { Aspergillus spp. } \\
\text { by molecular } \\
\text { diagnosis, } \\
\text { culture or } \\
\text { pathological } \\
\text { findings }\end{array}$ & $\begin{array}{l}\text { Positive } \\
\text { serologic test } \\
\text { required by both } \\
\text { of the following: } \\
\text { precipitins by } \\
\text { CIE with } \geq 2 \\
\text { lines, second } \\
\text { serologic test } \\
\text { positive by any } \\
\text { method; and } \\
\text { microbiological } \\
\text { evidence by } 1 \text { of } \\
\text { the following } \\
\text { sources from } \\
\text { BAL or sputum } \\
\text { samples: } \geq 2 \text { or } \\
\text { more positive } \\
\text { cultures, } 1 \\
\text { positive culture } \\
\text { and positive } \\
\text { microscopy }\end{array}$ & $\begin{array}{l}\text { Culture from } \\
\text { sputum or BAL } \\
\text { mandatory, } \\
\text { antibodies not } \\
\text { required }\end{array}$ & $\begin{array}{c}\text { Either raised } \\
\text { Aspergillus-specific } \\
\text { IgG or culture from } \\
\text { pulmonary or } \\
\text { pleural cavity }\end{array}$ & $\begin{array}{l}\text { If fungal ball present: } \\
\text { Aspergillus- } \\
\text { IgG/precipitins or other } \\
\text { evidence of } \\
\text { Aspergillus. If no } \\
\text { fungal ball but } \geq 1 \\
\text { cavities, then any of } \\
\text { the following: } \\
\text { Aspergillus-specific } \\
\text { IgG, Aspergillus } \\
\text { precipitins, strongly } \\
\text { positive Aspergillus } \\
\text { antigen or DNA in } \\
\text { respiratory fluids, } \\
\text { percutaneous or } \\
\text { excision biopsy } \\
\text { showing fungal } \\
\text { hyphae on } \\
\text { microscopy, growing } \\
\text { Aspergillus from a } \\
\text { cavity. These tests on } \\
\text { respiratory samples } \\
\text { not sufficient in } \\
\text { isolation: culture, } \\
\text { PCR, microscopy }\end{array}$ \\
\hline $\begin{array}{l}\text { Inflammatory } \\
\text { markers }\end{array}$ & $\begin{array}{c}\text { Raised levels of } \\
\text { either: CRP, ESR, } \\
\text { plasma viscosity }\end{array}$ & $\begin{array}{c}\geq 1 \text { of the } \\
\text { following raised: } \\
\text { leukocyte count, } \\
\text { CRP, ESR }\end{array}$ & Not required & Not required & $\begin{array}{l}\text { Raised levels of } \\
\text { either: CRP, ESR }\end{array}$ & Not required \\
\hline $\begin{array}{l}\text { Exclusion of } \\
\text { other } \\
\text { pathogens }\end{array}$ & $\begin{array}{l}\text { Required with the } \\
\text { following examples: } \\
\text { mycobacteria, } \\
\text { endemic mycoses }\end{array}$ & $\begin{array}{c}\text { Lack of } \\
\text { improvement } \\
\text { with } \geq 3 \mathrm{~d} \text { of } \\
\text { broad-spectrum } \\
\text { antimicrobial } \\
\text { drugs required; } \\
\text { patients with } \\
\text { infectious } \\
\text { diseases } \\
\text { other than } \\
\text { aspergillosis } \\
\text { excluded }\end{array}$ & Not required & $\begin{array}{c}\text { Required with } \\
\text { the following } \\
\text { examples: TB, } \\
\text { other mycoses, } \\
\text { granulomatosis } \\
\text { with polyangiitis, } \\
\text { ABPA, invasive } \\
\text { aspergillosis, } \\
\text { simple } \\
\text { aspergilloma† }\end{array}$ & $\begin{array}{l}\text { Not specifically } \\
\text { required }\end{array}$ & $\begin{array}{l}\text { Required with the } \\
\text { following examples: } \\
\text { TB, atypical } \\
\text { mycobacteria, } \\
\text { necrotizing lung } \\
\text { cancer, pulmonary } \\
\text { infarction, vasculitides, } \\
\text { rheumatoid nodule, } \\
\text { histoplasmosis/ } \\
\text { coccidioidomycosis/ } \\
\text { paracoccidioido- } \\
\text { mycosis in those with } \\
\text { relevant travel history }\end{array}$ \\
\hline 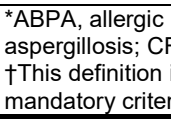 & CNPA cases wi & $\begin{array}{l}\text { nputed tomogr } \\
\text { mo symptom }\end{array}$ & - prouprat & ntorimmin & 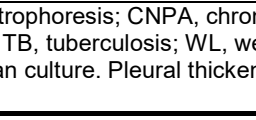 & $\begin{array}{l}\text { ic necrotizing pulmonary } \\
\text { ight loss. } \\
\text { ing seems to be a }\end{array}$ \\
\hline
\end{tabular}




\section{Clinical Features}

\section{Underlying Diseases}

Most CPA patients have prior or concurrent underlying pulmonary disease. Possible risk factors for development of CPA are cavities in the lung caused by pulmonary TB, sarcoidosis, previous Pneumocystis pneumonia, bullae or lung cysts, lung abscess, pulmonary infarction, pulmonary fibrosis, healed abscess cavities, cavitary bronchogenic carcinoma, and infection by NTM (21,26-30). In many countries, pulmonary TB is the most common disorder that precedes CPA (9). The most common differential diagnosis is pulmonary mycobacterial infection.

\section{Duration}

The duration of disease required to define CPA used by previous studies has been 1-6 months, usually 3 months. (Table 1). The expert panel consensus was to endorse a 3-month duration as a criterion for diagnosis of CPA. In patients with preexisting pulmonary disease, who often have chronic signs and symptoms, a change in pattern or severity of clinical presentation is considered the trigger point for the 3-month duration. In patients with few or unchanged signs and symptoms, documentation of 3-month duration may also be confirmed with radiographic findings of progression of cavitation, pericavitary infiltrates or fibrosis, development of a fungal ball (which takes weeks to form), or microbiological data.

\section{Signs and Symptoms}

Most patients with CPA experience clinical signs and symptoms, although some are asymptomatic and show progression radiologically only. The most distinctive and alarming sign is hemoptysis/hemosputum. Hemoptysis develops in $\approx 12 \%-43 \%$ of CPA patients $(23,25,31,32)$ and varies from blood streaking in sputum to massive and fatal hemoptysis. Hemoptysis may occur in patients with TB, but it is only streaking of sputum with blood and usually not severe. Another characteristic symptom is mild but persistent chest pain, discomfort, or tightness, experienced by up to $37 \%$ of patients. Weight loss and fatigue are also common, although not universal. Cough (usually productive) and dyspnea are common but not sufficiently distinctive to distinguish CPA from other pulmonary disorders, including pulmonary TB. Fever or pyrexia is uncommon in CPA patients and, if present, may indicate a concurrent or alternative diagnosis or subacute invasive aspergillosis. Night or day sweats are occasionally reported but are not discriminatory.

The consensus of the panel was that the diagnosis of CPA required the presence of $\geq 1$ symptoms persisting for 3 months and radiologic progression, a scenario present in most cases. Two other clinical scenarios that also qualify for the diagnosis of CPA are radiologic evidence of a simple aspergilloma (with or without symptoms) and characteristic radiologic appearance without symptoms but showing definite radiologic progression.

\section{Radiologic Criteria}

The focus of the discussion revolved around use of chest radiographs alone to diagnose $\mathrm{CPA}$; requiring computed tomography (CT), which is often unavailable, might delay diagnosis. Multiple studies have demonstrated that CT is more sensitive than chest radiography for demonstrating several features, namely, $\geq 1$ fungal balls, pulmonary nodules, multiple cavities, and disease in the apices and retrocardiac space (33). Considering the limited availability of CT in many healthcare settings, the radiologic criteria adopted are based solely on chest radiograph findings. Where available, CT is recommended in the context of clinical and microbiological suspicion of CPA with a nondiagnostic chest radiograph.

\section{Fungal Ball or Aspergilloma, Intracavitary Material, or Fluid Level on Chest Radiograph}

The differential diagnosis for a fungal ball in the lung is limited: echinoccocal cyst, necrotizing bronchogenic carcinoma, or acute or subacute invasive fungal infection. Similar-appearing conditions are lung abscess, Rasmussen aneurysm in a tuberculous cavity, cavitating hematoma, or lung infarct (34). If single and in a localized area of lung, with few or no symptoms, a simple aspergilloma is the most precise diagnosis (Figure 1) and can be resected or observed without antifungal treatment. Although presence of a fungal ball is highly suggestive of an aspergilloma as a manifestation of CPA, microbiological confirmation is required for a definitive diagnosis.

Occasionally, a fluid level is visible in cavities. Few of these cavities have been sampled with aspiration and microbiological analysis, but when done, cultures are usually positive for A. fumigatus or, less commonly, Staphylococcus aureus, Pseudomonas aeruginosa, and other pathogens. Therefore, a fluid level in a cavity is entirely consistent with CPA but may also represent co-infection (35).

\section{Cavitation}

The cardinal feature of CPA is the presence of $\geq 1$ cavities. The cavities may be small or large; may have thick or, less commonly, thin walls; and usually abut the pleura $(33,36)$. The cavities expand and may coalesce during progression of infection. In patients with extensive bullous emphysema, inflammation around a bulla may resemble cavitation. The differential diagnosis of chronic cavitary lesions includes mycobacterial infection, endemic fungal infection, and malignancy (37). The cavities seen with CPA are often located in the upper lung zone and may mimic TB; in patients with NTM infection and endemic fungal 


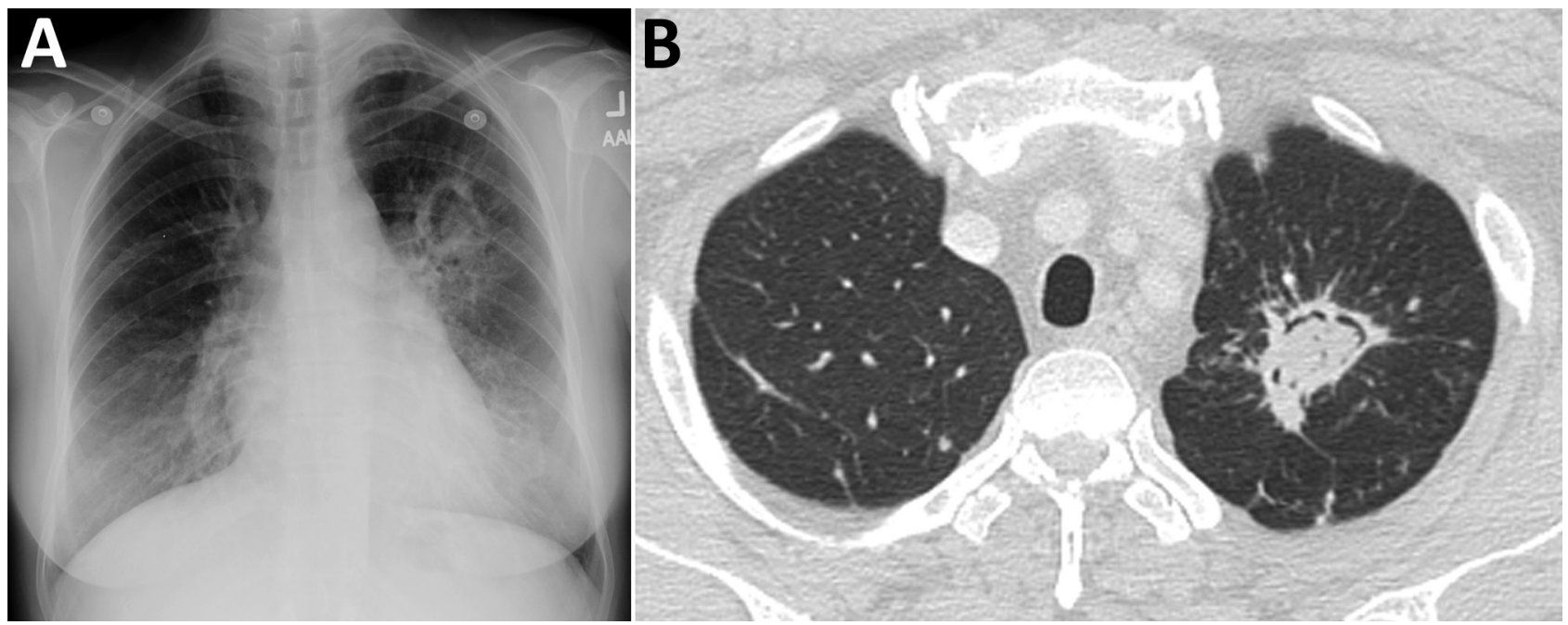

Figure 1. A) Chest radiograph showing aspergilloma (fungal ball) in the left upper lung lobe. B) Axial computed tomography image shows increased density in an irregular left apical cavity, a sequela of pulmonary tuberculosis, consistent with an aspergilloma.

diseases, the cavities may be located in any lung zone. A distinguishing feature of $\mathrm{CPA}$ is slow progression of findings over months or years, whereas active pulmonary TB infection progresses faster $(34,38)$ (Figure 2). Patients with NTM infection may also have cavitary lesions; however, lesions are more common among older white men with underlying lung disease (39). Patients with residual coccidioidal or other infectious cavities are usually asymptomatic unless these conditions are complicated by aspergilloma or superinfected (40). Cavitary bronchogenic carcinoma is usually associated with adenopathy and often pleural effusion.

\section{Pleural Thickening}

In the pre-CT era, pleural thickening was regarded as a sign of aspergilloma; indeed, pleural thickening is common in patients with CPA $(34,38)$. For many patients, pleural thickening seen on CT images usually consists of 2 components: fibrosis of the pleura overlying a cavity or area of consolidation and indrawing of extrapleural fat (typically seen in chronic inflammatory processes of the lung). This subtle distinction cannot be made readily from a chest radiograph. Pleural thickening should be regarded as a common feature of CPA and useful for diagnosis. Furthermore, pleural thickening is a specific feature of CPA, rarely seen in patients with TB or chronic coccidioidal or other fungal cavities $(40,41)$. Tuberculous empyema is usually exhibited as a large pleural effusion (42) and is commonly accompanied by interlobular septal thickening and micronodules (43). Cavitating bronchogenic carcinoma may invade the chest wall causing bone destruction or may cause diffuse pleural

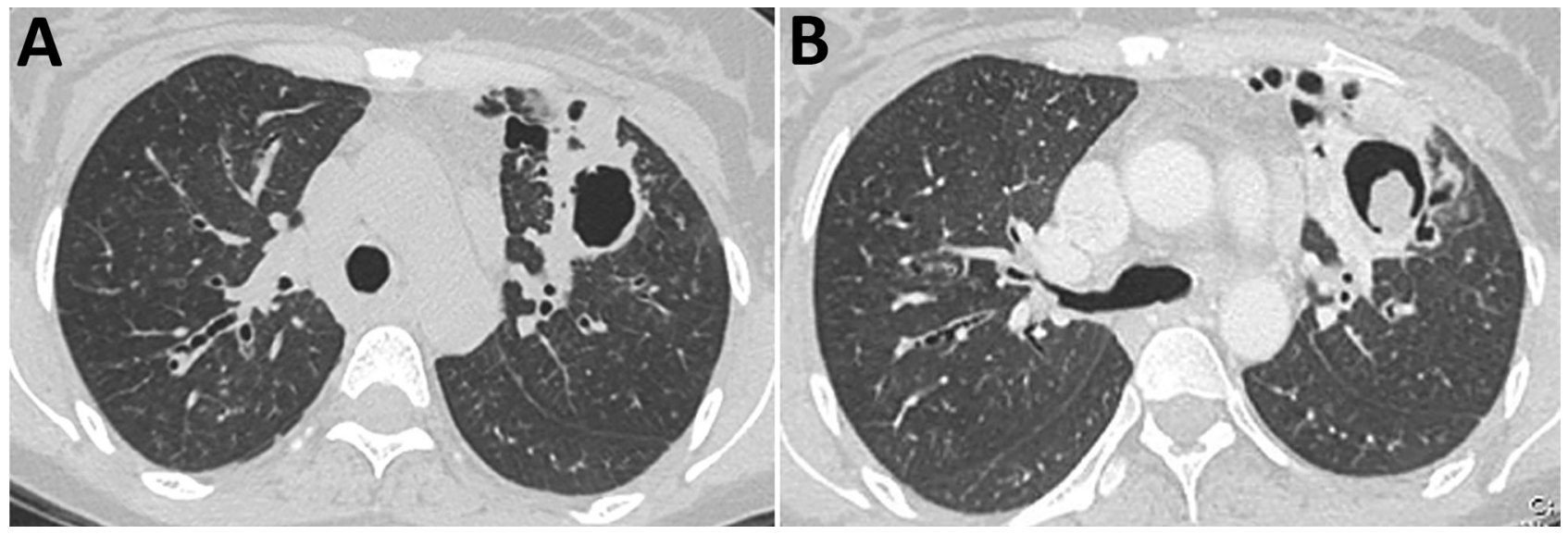

Figure 2. Computed tomography images of a patient with chronic pulmonary aspergillosis. A) Left upper lung lobe thick-walled cavity, showing associated pleural thickening. B) Same patient several months later, demonstrating progression of cavitation with increased pericavitary consolidation and formation of a fungal ball within the cavity. Aspergilloma formation is a late feature of chronic pulmonary aspergillosis. 
involvement; however, these manifestations are distinct from the focal pleural thickening associated with CPA.

\section{Pericavitary Infiltration}

The inflammatory changes seen adjacent to cavities in patients with CPA are often marked, reflecting inflammation but not hyphal invasion. These areas may merge with localized areas of fibrosis, pleural thickening, or both but are usually obvious on plain chest radiographs (36); they indicate active CPA and are a clear indication for therapy (44). Such pericavitary infiltrates, unless very extensive, are uncommon in reactivation of TB and NTM disease. Pericavitary consolidation may be seen in patients with chronic fibrocavitary coccidioidomycosis (40).

\section{CT Image Features}

One radiologic aspect of CPA not characterized on a chest radiograph is the interior of a cavity. Aspergillus grows inside the cavity along the wall, resulting in an irregular appearance of the inner border seen on CT images. In addition, the cavity may contain linear opacities representing mats of fungal growth that have detached from the cavity wall (38). These growths often merge to form sponge-like densities, which can be described as a fungal ball containing air (45). These structures may detach from the cavity wall and may be mobile. For purposes of the definitions outlined in this article, all these characteristic features are deemed to be equivalent to a fungal ball (Figure 3). With antifungal therapy, they resolve more readily than an aspergilloma.

One feature for which CT is much more sensitive than chest radiography is the Aspergillus nodule, particularly when the nodule is small (46). These nodules may have a maximum diameter of $5-50 \mathrm{~mm}$, may be single or multiple, and may be solid or have central cavitation. Larger nodules $(>3 \mathrm{~cm})$ are more accurately described as masses, which may also be attributable to Aspergillus infection. The differential diagnosis of the Aspergillus nodule is broad and includes carcinoma (primary or secondary), coccidioidomycosis, cryptococcosis, NTM infection, and others.

Establishing a definitive diagnosis of a nodule usually requires resection or biopsy, especially because many patients do not have elevated IgG against Aspergillus or positive sputum cultures $(47,48)$. Because these diagnostic procedures are not available in many medical centers in lower- and middle-income countries, we elected to consider these separately and not include them in our operational definition.

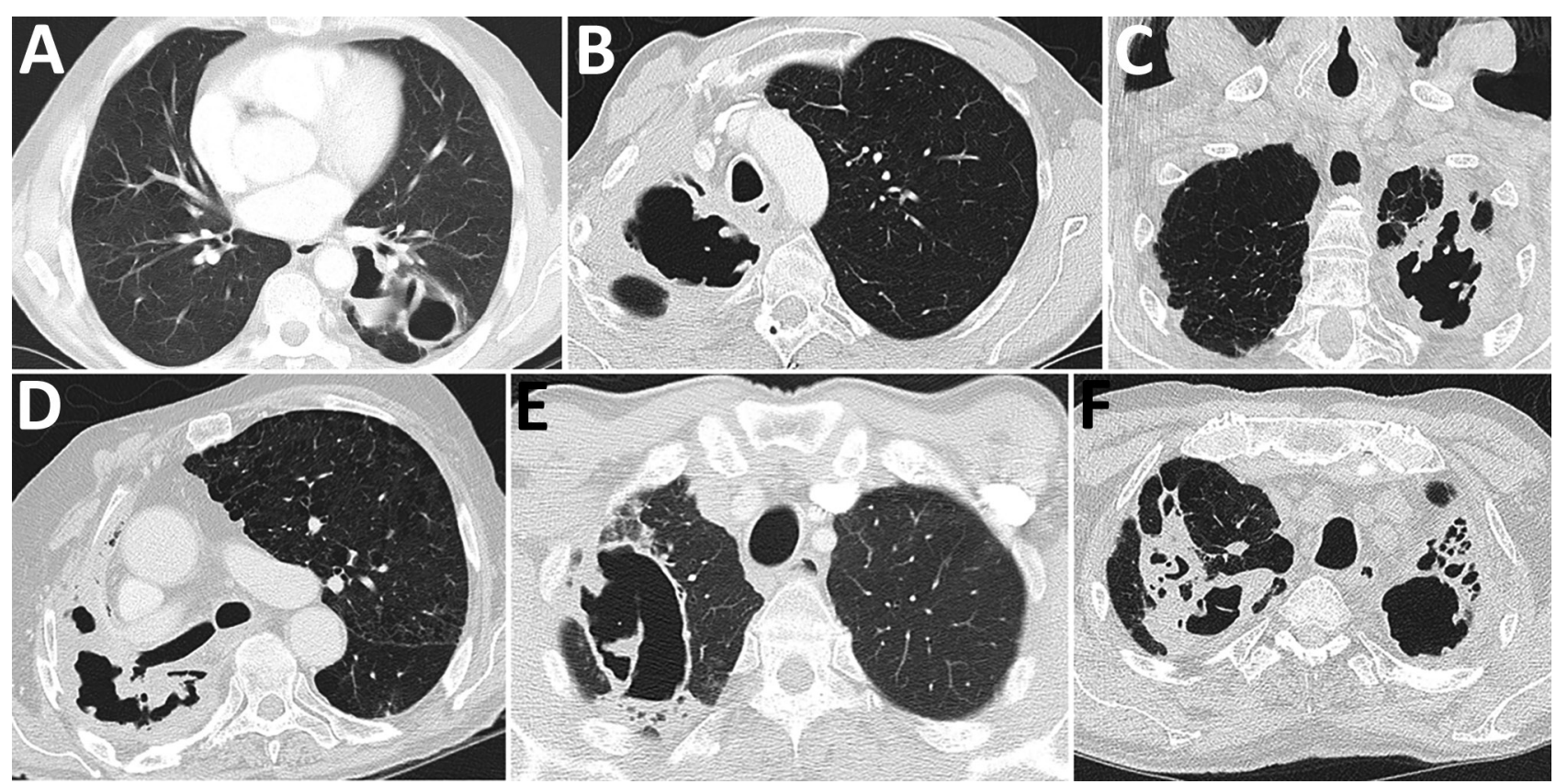

Figure 3. Computed tomography images showing early features of fungal ball formation in pulmonary cavities. A) Two left lower lung lobe posterior thick-walled cavities, 1 with a fluid level. B) Two right apical cavities, the larger with an irregular interior wall, most consistent with fungal growth. C) Left apex replaced by an irregular thick-walled cavity with multiple areas of fungal growth on the interior surface of the cavity. D) Substantial volume loss in the right upper lobe with replacement by a small anterior cavity and larger crescent-shaped cavity with both pleural thickening and fat indrawing along the pleural surface posteriorly. The cavity shows marked irregularity consistent with fungal growth. E) A right upper lobe thin-walled cavity containing 2 areas of fungal growth, 1 of which has detached from the wall as a thick mat of mycelial growth with a larger lump in the cavity interior. F) Multiple cavities in both upper lobes, with wall irregularity in the left upper lobe cavity consistent with surface fugal growth. The right upper lobe cavity shows pleural thickening and indrawing of fat posteriorly. 


\section{Culture-Based and Non-Culture-Based Evidence of Aspergillosis}

The most reliable diagnostic test for CPA is a positive Aspergillus antibody test result, indicative of an immune response to Aspergillus. The second most reliable diagnostic marker for CPA is detection of Aspergillus in the airways by use of culture, antigen, and/or nucleic acid amplification (PCR).

\section{Antibodies against Aspergillus}

Elevated circulating levels of Aspergillus antibodies are present in $>95 \%$ but $<100 \%$ of patients (49-51). Most commercial assays detect $A$. fumigatus $\mathrm{IgG}$; however, CPA is occasionally caused by other Aspergillus species, resulting in false-negative results. In addition, some patients with CPA are subtly immunocompromised, as has been documented with nonprotective pneumococcal or Haemophilus antibodies (52); low circulating CD4 (T helper), CD19 (B cell), or CD56 (natural killer) cell counts (53); and poor production of gamma interferon interleukin 17A, interleukin 12 , or both (54). Such patients may not mount a detectable IgG response. Many patients have detectable A. fumigatus $\operatorname{IgE}$ and elevated total $\operatorname{IgE}$ in the absence of any other features of allergic Aspergillus disease (21).

Serologic testing for Aspergillus relies mainly on the detection of $\operatorname{IgG}$ and of precipitating antibodies (known as precipitins), which may be IgG or IgM. Precipitin detection requires immunodiffusion and electrophoresis migration methods, which lack standardization and are too laborious and time-consuming for resource-constrained settings. Consequently, we focused on commercially available enzyme immunoassay kits that detect IgG. Up to 2015, there were few direct comparisons of A. fumigatus serology (55), but more recently, several have been published (Table 2). Crucial to these comparisons is defining the cutoff values for each assay. The control groups of patients used for such comparisons have included healthy persons or those with pulmonary disease without aspergillosis. Few data on antibody titer associations with age, HIV status, or ethnicity of controls are available. New lateral flow devices for Aspergillus antibody detection are in the final stages of development and, if their performance is good, could greatly facilitate diagnosis. The consensus of the expert panel was that any Aspergillus antibody test performance had to be at least $90 \%$ sensitive and $85 \%$ specific.

An elevated level of Aspergillus IgG is consistent with several conditions, including Aspergillus rhinosinusitis, allergic bronchopulmonary aspergillosis, Aspergillus bronchitis (notably in cystic fibrosis and bronchiectasis), subacute invasive aspergillosis, recovery from invasive aspergillosis, and community-acquired Aspergillus pneumonia. Because an elevated level of IgG is highly sensitive but not specific for CPA, the diagnosis of CPA requires the presence of compatible symptoms and radiologic abnormalities.

\section{Respiratory Tract Microscopy and Culture}

Microscopy of sputum may show hyphae morphologically consistent with Aspergillus spp. If present, this finding is most consistent with CPA or Aspergillus tracheobronchitis (63). Despite the substantial amount of Aspergillus spp. in the cavities of patients with CPA, culture positivity from sputum samples is lower than expected (41\%-81\%) and is probably biased toward culture-positive cases $(21,22,64-67)$. One reason for this lower sensitivity is the inoculation of culture plates with very small volumes of sputum $(65,68)$ as is done for bacterial culture. Negative cultures might reflect an inability of the fungus to adapt to in vitro conditions, despite the apparent ease with which environmental contamination occurs in the laboratory.

The merits of positive culture results are substantial, notably for identifying the Aspergillus species causing infection and enabling susceptibility testing to be performed. False-positive cultures do occur as a result of laboratory contamination. Although most CPA cases are caused by $A$. fumigatus complex (probably sensu stricto), A. niger complex and A. flavus complex and rare cases caused by unusual pathogenic species are reported. In countries such as India, where A. flavus infection is much more common, it is not clear what proportion of cases are attributable to non-A. fumigatus species. Most triazole-resistant $A$. fumigatus isolated from patients with CPA has arisen while the patient was receiving therapy and probably result from large fungal loads or low drug exposure (low dose, drug interactions, poor bioavailability) (69). Isolates may be resistant or have intermediate susceptibility to 1-4 triazoles.

\section{Aspergillus Antigen and $\beta$-1,3-D-glucan}

Galactomannan is a detectable carbohydrate antigen produced by the growth of Aspergillus spp. Galactomannan detection is useful for the diagnosis of invasive aspergillosis because it is often detectable in serum and bronchoalveolar lavage (BAL) fluid. Because tissue invasion does not occur in patients with CPA, galactomannan is not usually detectable in serum and is usually detectable in BAL fluid only $(59,70)$. This finding is of limited utility in lower- and middle-income countries because fiberoptic bronchoscopy is infrequently done. Galactomannan is detectable in sputum or tracheal secretions/aspirates, but the cutoff for positivity is not established (71).

A new simple lateral flow assay for different protein antigens specific to A. fumigatus has been commercialized, but no data are available on sputum detection or its utility for patients with CPA. This assay is unlikely to be useful in serum because of antibody masking but may be useful 
Table 2. Performance of commercially available Aspergillus diagnostic serology tests for CPA*

\begin{tabular}{|c|c|c|c|c|c|c|}
\hline Ref. & Study population, location & Assay† & Cutoff & Sensitivity, \% & Specificity, \% & ROC/AUC (95\% Cl) \\
\hline$(56)$ & 28 CPA patients & $\begin{array}{c}\text { DD, Microgen } \\
\text { Bio-Rad galactomannan }\end{array}$ & $\begin{array}{c}- \\
\text { GM index }>0.5\end{array}$ & $\begin{array}{c}89.3 \\
50\end{array}$ & $\begin{array}{l}\text { ND } \\
\text { ND }\end{array}$ & $\begin{array}{l}\text { ND } \\
\text { ND }\end{array}$ \\
\hline \multirow[t]{2}{*}{ (57) } & $\begin{array}{l}51 \text { CPA patients, } 341 \\
\text { controls } \ddagger\end{array}$ & $\begin{array}{l}\text { Bio-Rad Platelia } \\
\text { Aspergillus IgG }\end{array}$ & $10 \mathrm{AU} / \mathrm{mL}$ & 90.2 & 89.6 & ND \\
\hline & & $\begin{array}{l}\text { Serion/Virion ELISA } \\
\text { classic Aspergillus IgG }\end{array}$ & $70 \mathrm{AU} / \mathrm{mL}$ & 88.8 & 84.4 & ND \\
\hline \multirow[t]{2}{*}{ (25) } & 49 SA patients & IBL culture filtrate ELISA & ND & 99 & ND & ND \\
\hline & & Bio-Rad galactomannan & GM index $>0.5$ & 23 & ND & ND \\
\hline \multirow[t]{3}{*}{$(58)$} & 116 CPA patients & $\begin{array}{l}\text { Bio-Rad Platelia } \\
\text { Aspergillus IgG }\end{array}$ & $10 \mathrm{AU} / \mathrm{mL}$ & 86 & ND & ND \\
\hline & & $\begin{array}{c}\text { ThermoFisher Scientific } \\
\text { ImmunoCAP }\end{array}$ & $40 \mathrm{mg} / \mathrm{L}$ & 85 & ND & ND \\
\hline & & DD & & 56 & ND & ND \\
\hline \multirow[t]{2}{*}{ (59) } & 168 CPA patients & Bio-Rad galactomannan & GM index $>0.5$ & 23 & ND & $0.538(0.496-0.580)$ \\
\hline & & DD & ND & 98 & ND & ND \\
\hline$(60)$ & $\begin{array}{c}89 \text { CPA patients, } 10 \\
\text { aspergilloma patients, } \\
212 \text { blood healthy donors }\end{array}$ & $\begin{array}{l}\text { Aspergillus LDBio } \\
\text { Western blot IgG kit }\end{array}$ & ND & $\begin{array}{l}\text { CPA, 91.0; } \\
\text { aspergilloma, } \\
90.0\end{array}$ & ND & ND \\
\hline \multirow[t]{6}{*}{ (49) } & $\begin{array}{l}\text { 241 CPA patients, } 100 \\
\text { blood donors, Uganda }\end{array}$ & Dynamiker & $65 \mathrm{AU} / \mathrm{mL}$ & 77 & 97 & $0.918(0.89-0.946)$ \\
\hline & & $\begin{array}{c}\text { Omega (Genesis) } \\
\text { Aspergillus IgG ELISA } \\
\text { kit }\end{array}$ & $20 \mathrm{AU} / \mathrm{mL}$ & 75 & 99 & $0.902(0.871-0.933)$ \\
\hline & & Immulite Siemens & $10 \mathrm{mg} / \mathrm{L}$ & 96 & 98 & $0.991(0.982-1)$ \\
\hline & & $\begin{array}{l}\text { ThermoFisher Scientific } \\
\text { Immunocap }\end{array}$ & $20 \mathrm{mg} / \mathrm{L}$ & 96 & 98 & $0.996(0.992-1)$ \\
\hline & & $\begin{array}{l}\text { Serion/Virion ELISA } \\
\text { classic Aspergillus IgG }\end{array}$ & $35 \mathrm{AU} / \mathrm{mL}$ & 90 & 98 & $0.973(0.96-0.987)$ \\
\hline & & Precipitins (Microgen) & ND & 59 & 100 & ND \\
\hline \multirow[t]{3}{*}{$(50)$} & $\begin{array}{c}17 \text { SA patients, } 62 \text { CPA } \\
\text { patients, } 25 \text { CNPA } \\
\text { patients, } 205 \text { controls } \S\end{array}$ & Bordier & $\mathrm{OD}>1$ & $\begin{array}{l}\text { SA, 95.6; CPA, } \\
\text { 97.4; CNPA: } 100\end{array}$ & 90.3 & $0.997(0.962-0.991)$ \\
\hline & & $\begin{array}{l}\text { Bio-Rad Platelia } \\
\text { Aspergillus IgG }\end{array}$ & $10 \mathrm{AU} / \mathrm{mL}$ & $\begin{array}{l}\text { SA, 95.6; CPA, } \\
97.4 ; \text { CNPA, } 100\end{array}$ & 91.3 & $0.951(0.928-0.974)$ \\
\hline & & $\begin{array}{l}\text { Serion/Virion ELISA } \\
\text { classic Aspergillus IgG }\end{array}$ & $70 \mathrm{AU} / \mathrm{mL}$ & $\begin{array}{c}\text { SA, 78.3; CPA, } \\
\text { 82.0; CNPA, } \\
82.9\end{array}$ & 81.5 & $0.897(0.863-0.931)$ \\
\hline (51) & 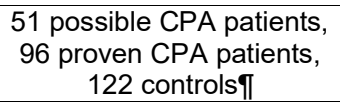 & $\begin{array}{l}\text { ThermoFisher Scientific } \\
\text { ImmunoCAP }\end{array}$ & $50 \mathrm{mg} / \mathrm{L}$ & $\begin{array}{l}\text { Possible CPA, } \\
39.2 ; \text { proven } \\
\text { CPA, } 97.9\end{array}$ & ND & $0.94(0.912-0.972)$ \\
\hline \multirow[t]{4}{*}{ (61) } & $\begin{array}{l}241 \text { CPA patients, } 152 \\
\text { healthy controls, the } \\
\text { Netherlands }\end{array}$ & Siemens Immulite & $25 \mathrm{mg} / \mathrm{L}$ & 92.9 & 99.3 & $0.948(0.921-0.975)$ \\
\hline & $\begin{array}{c}241 \text { CPA patients, } 141 \\
\text { healthy controls, Belgium }\end{array}$ & $\begin{array}{c}\text { ThermoFisher Scientific } \\
\text { ImmunoCAP }\end{array}$ & $50 \mathrm{mg} / \mathrm{L}$ & 83.8 & 95.6 & $0.956(0.937-0.974)$ \\
\hline & $\begin{array}{l}241 \text { CPA patients, } 222 \\
\text { healthy controls, France }\end{array}$ & Serion & $50 \mathrm{U} / \mathrm{mL}$ & 84.2 & 91 & $0.944(0.925-0.964)$ \\
\hline & $\begin{array}{c}118 \text { CPA patients, } 222 \\
\text { healthy controls, France }\end{array}$ & Bio-Rad & $1.5 \mathrm{AU} / \mathrm{mL}$ & 93.2 & 98.2 & $0.955(0.922-0.988)$ \\
\hline \multirow[t]{3}{*}{$(62)$} & $\begin{array}{l}241 \text { CPA patients, } 299 \\
\text { healthy controls, Uganda }\end{array}$ & Siemens Immulite & $15 \mathrm{mg} / \mathrm{L}$ & 94.6 & 98 & $0.984(0.972-0.997)$ \\
\hline & $\begin{array}{l}241 \text { CPA patients, } 398 \\
\text { patients with treated TB, } \\
\text { Uganda }\end{array}$ & Siemens Immulite & $15 \mathrm{mg} / \mathrm{L}$ & 94.6 & 94.5 & $0.972(0.959-0.985)$ \\
\hline & 241 CPA patients, 234 & Siemens Immulite & $25 \mathrm{mg} / \mathrm{L}$ & 92.9 & 98.7 & $0.979(0.967-0.992)$ \\
\hline
\end{tabular}

patients with treated TB,

radiologically screened for CPA, Uganda

${ }^{*} \mathrm{AU}$, absorbance units; CPA, chronic pulmonary aspergillosis; CNPA, chronic necrotizing pulmonary aspergillosis; DD, double diffusion (precipitins); GM, galactomannan; ND, not determined (did not test enough control serum to assess); OD, optical density; Ref, reference; ROC/AUC, receiver operating characteristic/area under the curve; SA, simple aspergilloma; TB, tuberculosis; -, not applicable.

†Bio-Rad, Marnes-la-Coquette, France; Bordier, Crissier, Switzerland; DD, in-house test (58); Dynamiker, Tianjin, China; IBL, Hamburg, Germany; LDBio Diagnostics, Lyon, France; Microgen, Camberley, UK; Omega, Alva, Scotland, UK; Serion/Virion, Würzburg, Germany; Siemens, Camberley, UK; ThermoFisher, Uppsala, Switzerland.

łPopulation included 26 patients with Aspergillus bronchial colonization, 44 patients with 1 positive Aspergillus culture considered as colonization, 49 patients with negative microbiological results, and 222 pregnant women.

$\S$ Control groups comprised 14 patients colonized with Aspergillus and 191 patients with respiratory symptoms.

TPossible CPA, Aspergillus precipitin negative and a persistently elevated inflammation marker; proven CPA, Aspergillus precipitin positive and a persistently elevated inflammation marker; control, other chronic respiratory disease (any Aspergillus precipitin and temporary elevated inflammation marker). 
Table 3. Final consensus definition of CPA in resource-constrained settings, determined by Global Action Fund for Fungal Infections international expert panel ${ }^{*}$

\begin{tabular}{|c|c|}
\hline Required criteria† & Details \\
\hline Symptoms for $\geq 3 \mathrm{mo}$ & $\begin{array}{l}\text { Hemoptysis and/or persistent cough, and/or weight loss; other } \\
\text { symptoms are common, but not required, notably fatigue, chest } \\
\text { pain, dyspnea, and sputum production }\end{array}$ \\
\hline Radiologic features & $\begin{array}{c}\text { Progressive cavitation on chest imaging and/or intracavitary } \\
\text { fungal ball and/or pleural thickening or pericavitary fibrosis } \\
\text { or infiltrates all adjacent to cavities }\end{array}$ \\
\hline Microbiological evidence of Aspergillus infection & $\begin{array}{l}\text { Positive Aspergillus-specific IgG and/or sputum microscopy } \\
\text { results showing hyphae consistent with Aspergillus and/or } \\
\text { Aspergillus growth on } \geq 2 \text { sputum or other respiratory samples }\end{array}$ \\
\hline $\begin{array}{l}\text { Mycobacterial infection ruled out with smear, GeneXpert, and/or } \\
\text { mycobacterial culture } \neq\end{array}$ & $\begin{array}{l}\text { It is possible for mycobacterial infection and CPA to be present } \\
\text { concurrently, but this diagnosis requires characteristic radiological } \\
\text { findings on CT scan that are not present with pulmonary TB } \\
\text { including pleural thickening, a fungal ball or other intracavitary } \\
\text { material, or marked pericavitary infiltrates in addition to a positive } \\
\text { Aspergillus IgG antibody test }\end{array}$ \\
\hline
\end{tabular}

${ }^{*} \mathrm{CPA}$, chronic pulmonary aspergillosis; CT, computed tomography; TB, tuberculosis.

†All 4 criteria are required.

¥GeneXpert (http://www.cepheid.com/us/cepheid-solutions/systems/genexpert-systems/genexpert-iv).

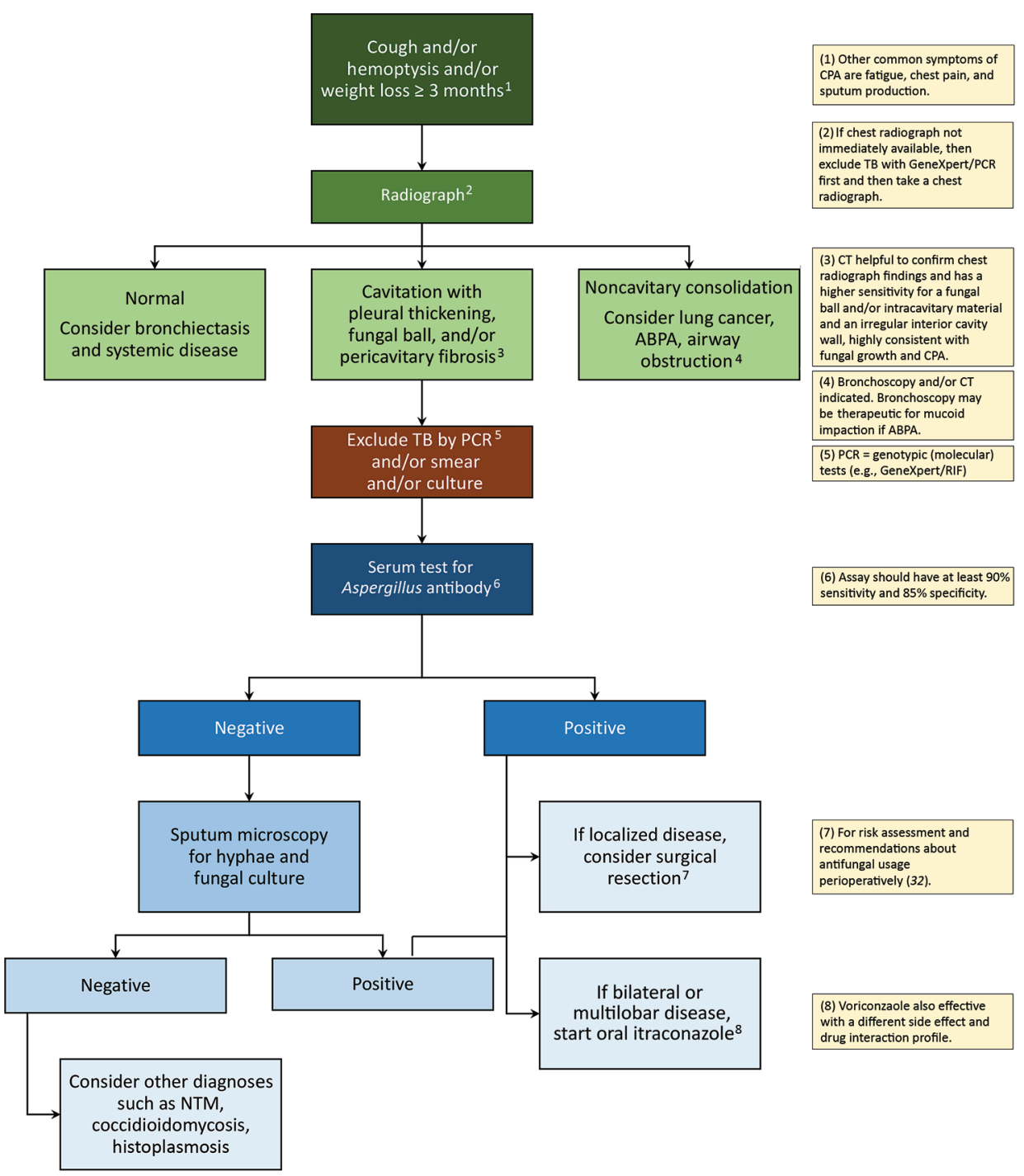

Figure 4. Diagnostic algorithm incorporating the chest radiographic appearance and results of rapid TB investigations with the case definition of CPA. ABPA, allergic bronchopulmonary aspergillosis; CPA, chronic pulmonary aspergillosis; CT, computed tomography; NTM, nontuberculous mycobacteria; TB, tuberculosis. GeneXpert, http://www.cepheid.com/us/ cepheid-solutions/systems/ genexpert-systems/genexpert-iv entifungal usage 
in BAL fluid $(72,73)$. $\beta-1,3-\mathrm{D}$-glucan is released by Aspergillus spp. (and many other fungi) during infection but is less specific and probably not more sensitive than serum galactomannan in patients with CPA.

\section{Molecular Detection of Aspergillus}

For patients with CPA, PCR detection of Aspergillus spp. in sputum is significantly more sensitive than culture (63). However, the quality and possibly quantity of the sputum sample influence PCR performance (71). Furthermore, studies have shown that the sensitivity of PCR for detection of Aspergillus is $\approx 80 \%$. Depending on the cutoff value used, low specificity may also be an issue. Molecular assays for Aspergillus spp. are not routinely available in most medical centers worldwide, especially in lower- and middle-income countries.

\section{Consensus Definition and Proposed Algorithm}

The definition of CPA recommended for use in resourceconstrained settings in shown in Table 3. In a patient who has had symptoms consistent with chronic Aspergillus infection for $>3$ months, a chest radiograph should be obtained (Figure 4). If a chest radiograph is not possible, then pulmonary TB should be excluded by examination of respiratory specimens. The chest radiograph appearance determines the next course of action. If the chest radiograph is not remarkable, the signs and symptoms may be caused by bronchiectasis or systemic disease. If the chest radiograph shows consolidation without cavitation, then other diagnoses such as lung malignancy, airway obstruction, or endemic fungal infections should be considered. If the chest radiograph shows cavitation, then work-up for possible pulmonary TB should be initiated according to national practice and standards. A positive result for pulmonary TB should lead to appropriate treatment. If the pulmonary TB results are negative, and especially if the radiographic findings include pleural thickening, fungal ball, or pericavitary fibrosis or infiltrates, serum should be tested for Aspergillus IgG (Figure 4). If the Aspergillus IgG test result is negative (or unavailable), then sputum microscopy for hyphae or fungal culture should be performed; yield is higher when multiple specimens are tested. If the sputum microscopy for hyphae or fungal culture is negative, then other diagnoses, such as atypical mycobacterial infection or endemic fungal infection, should be considered. If sputum microscopy for hyphae or culture is positive, or if a serum Aspergillus antibody test result is positive, then CPA is confirmed and treatment with itraconazole or voriconazole is advised (19).

\section{Conclusions}

We present recommendations for diagnosing CPA, adapted for clinical use and public health surveillance in resource- constrained settings. The adapted definition relies on a combination of signs and symptoms, chest radiograph features, and serologic evidence of Aspergillus infection; it is applicable to almost all patient groups in which CPA occurs. Prospective evaluation of the proposed definition and associated algorithms will be valuable in the contexts of different geographic and HIV and pulmonary TB burdens (74). We believe that the proposed operational definition of CPA in lower- and middle-income countries will facilitate advancements in research and practice (clinical, laboratory, radiologic, and public health) and policy (health services and public health) in these countries and globally in resource-constrained settings.

The workshop was funded by the Global Action Fund for Fungal Infections. Contributions toward the workshop were received from the European Confederation for Medical Mycology, European Society for Clinical Microbiology and Infectious Diseases, the International Society for Human and Animal Mycology, Miravista Diagnostics, Immy Inc., Pfizer Inc., Basliea Pharmaceutica, Gilead Sciences, Merck Inc., Cidara Therapeutics Inc., Viamet Pharmaceuticals, F2G Ltd., Pulmocide Ltd., and Scynexis Inc. Some workshop expenses were covered by the National Aspergillosis Centre, University Hospital of South Manchester.

D.W.D. and family hold Founder shares in F2G Ltd., a University of Manchester spin-out antifungal discovery company. D.W.D. acts or has recently acted as a consultant to Astellas, Sigma Tau, Basilea, Scynexis, Cidara, Biosergen, Quintiles, Pulmatrix, Fujifilm, Zambon, and Pulmocide. In the past 3 years, he has been paid for talks on behalf of Astellas, Dynamiker, Gilead, Merck, Mylan, and Pfizer. He is a longstanding member of the Infectious Disease Society of America Aspergillosis Guidelines group, the European Society for Clinical Microbiology and Infectious Diseases Aspergillosis Guidelines Group, and the British Society for Medical Mycology Standards of Care Committee. I.D.P. has received research grants, test kit donations, or both from Astellas, Siemens, Dynamiker, Serion/Virion, OLM Medical, and Genesis. C.M.J. is a consultant to Canon Medical Research USA and author of UpToDate, Inc. M.C. has been paid for talks on behalf of Astellas, Gilead, and Pfizer. A.A.-I. has received grants from Gilead Sciences, Scynexis, and F2G and has been paid for talks on behalf of Gilead. P.B. is a cofounder of Alergenetica SL and Syngenics Ltd. and has current grant support from Medical Research Council, Fungal Infection Trust, EU Framework 7, and the National Institutes of Health. M.H. has received a research grant from Gilead and served on the speakers' bureau of Gilead, Basilea, and Merck. K.I. has received research grants and honoraria from Pfizer Japan Inc., MSD K.K., Astellas Pharma Inc., and Dainippon Sumitomo Pharma Co. R.O.O. has received honoraria from Pfizer, Nigeria. M.D.R. acts as a consultant for Gilead Sciences, MSD, 
Pfizer, Astellas, Basilea, and Pulmocide and is a member of the European Society for Clinical Microbiology and Infectious Diseases Aspergillosis Guidelines Group. H.J.F.S. received honoraria from Chiesi and travel grants from Gilead. C.S. has received grants or conference support from the Fungal Infection Trust, European Society for Clinical Microbiology and Infectious Diseases, and MSD. None of the other authors report a conflict of interest.

\section{About the Author}

Dr. Denning, an infectious diseases clinician who is heavily involved in postgraduate teaching and lectures worldwide, leads LIFE (Leading International Fungal Education) and is president of the Global Action Fund for Fungal Infections. His primary research interests are chronic and allergic pulmonary fungal diseases, the global burden of fungal infection, and azole resistance in Aspergillus.

\section{References}

1. Goodwin RA Jr, Owens FT, Snell JD, Hubbard WW, Buchanan RD, Terry RT, et al. Chronic pulmonary histoplasmosis. Medicine (Baltimore). 1976;55:413-52. http://dx.doi.org/10.1097/00005792-197611000-00001

2. Shah A, Panjabi C. Allergic bronchopulmonary aspergillosis: a review of a disease with a worldwide distribution. J Asthma. 2002;39:273-89. http://dx.doi.org/10.1081/JAS-120002284

3. Chong S, Lee KS, Yi CA, Chung MJ, Kim TS, Han J. Pulmonary fungal infection: imaging findings in immunocompetent and immunocompromised patients. Eur J Radiol. 2006;59:371-83. http://dx.doi.org/10.1016/j.ejrad.2006.04.017

4. Chu HQ, Li B, Zhao L, Huang DD, Zhang ZM, Xu JF, et al. Chest imaging comparison between non-tuberculous and tuberculosis mycobacteria in sputum acid fast bacilli smear-positive patients. Eur Rev Med Pharmacol Sci. 2015;19:2429-39.

5. Chiang CY, Yu MC, Yang SL, Yen MY, Bai KJ. Surveillance of tuberculosis in Taipei: the influence of nontuberculous mycobacteria. PLoS One. 2015;10:e0142324. http://dx.doi.org/ 10.1371/journal.pone. 0142324

6. Getahun H, Harrington M, O’Brien R, Nunn P. Diagnosis of smear-negative pulmonary tuberculosis in people with HIV infection or AIDS in resource-constrained settings: informing urgent policy changes. Lancet. 2007;369:2042-9. http://dx.doi.org/ 10.1016/S0140-6736(07)60284-0

7. Schweer KE, Bangard C, Hekmat K, Cornely OA. Chronic pulmonary aspergillosis. Mycoses. 2014;57:257-70. http://dx.doi.org/10.1111/myc.12152

8. Pasipanodya JG, Miller TL, Vecino M, Munguia G, Bae S, Drewyer G, et al. Using the St. George respiratory questionnaire to ascertain health quality in persons with treated pulmonary tuberculosis. Chest. 2007;132:1591-8. http://dx.doi.org/10.1378/ chest.07-0755

9. Denning DW, Pleuvry A, Cole DC. Global burden of chronic pulmonary aspergillosis as a sequel to pulmonary tuberculosis. Bull World Health Organ. 2011;89:864-72. http://dx.doi.org/10.2471/ BLT.11.089441

10. Chakaya J, Kirenga B, Getahun H. Long term complications after completion of pulmonary tuberculosis treatment: a quest for a public health approach. J Clin TB Mycobact Dis 2016;3:10-12.

11. World Health Organization. 2015 Global Tuberculosis Report. Geneva: The Organization; 2015.
12. Hargreaves NJ, Kadzakumanja O, Phiri S, Lee CH, Tang X, Salaniponi FM, et al. Pneumocystis carinii pneumonia in patients being registered for smear-negative pulmonary tuberculosis in Malawi. Trans R Soc Trop Med Hyg. 2001;95:402-8. http://dx.doi.org/10.1016/S0035-9203(01)90197-X

13. Nakiyingi L, Ssengooba W, Nakanjako D, Armstrong D, Holshouser M, Kirenga BJ, et al. Predictors and outcomes of mycobacteremia among HIV-infected smear-negative presumptive tuberculosis patients in Uganda. BMC Infect Dis 2015;15:62.

14. Pohl C, Jugheli L, Haraka F, Mfinanga E, Said K, Reither K. Pulmonary aspergilloma: a treatment challenge in sub-Saharan Africa. PLoS Negl Trop Dis. 2013;7:e2352. http://dx.doi.org/ 10.1371/journal.pntd.0002352

15. British Tuberculosis Association. Aspergillus in persistent lung cavities after tuberculosis. A report from the Research Committee of the British Tuberculosis Association. Tubercle. 1968;49:1-11. http://dx.doi.org/10.1016/S0041-3879(68)80002-9

16. Smith NL, Denning DW. Underlying conditions in chronic pulmonary aspergillosis including simple aspergilloma. Eur Respir J. 2011;37:865-72. http://dx.doi.org/10.1183/ 09031936.00054810

17. The Lancet Respiratory Medicine. Chronic pulmonary aspergillosis: help is on the way. Lancet Respir Med 2016;4:83.

18. Patterson TF, Thompson GR III, Denning DW, Fishman JA, Hadley S, Herbrecht R, et al. Practice guidelines for the diagnosis and management of aspergillosis: 2016 update by the Infectious Diseases Society of America. Clin Infect Dis. 2016;63:e1-60. http://dx.doi.org/10.1093/cid/ciw326

19. Denning DW, Cadranel J, Beigelman-Aubry C, Ader F, Chakrabarti A, Blot S, et al.; European Society for Clinical Microbiology and Infectious Diseases and European Respiratory Society. Chronic pulmonary aspergillosis: rationale and clinical guidelines for diagnosis and management. Eur Respir J. 2016;47:45-68. http://dx.doi.org/10.1183/13993003.00583-2015

20. Kohno S, Tamura K, Niki Y, Izumikawa K, Oka S, Ogawa K, et al. Executive summary of Japanese Domestic Guidelines for Management of Deep-seated Mycosis 2014. Med Mycol J. 2016;57:E117-63. http://dx.doi.org/10.3314/mmj.16-00010

21. Denning DW, Riniotis K, Dobrashian R, Sambatakou H. Chronic cavitary and fibrosing pulmonary and pleural aspergillosis: case series, proposed nomenclature change, and review. Clin Infect Dis. 2003;37(Suppl 3):S265-80. http://dx.doi.org/10.1086/376526

22. Kohno S, Izumikawa K, Ogawa K, Kurashima A, Okimoto N, Amitani R, et al.; Japan Chronic Pulmonary Aspergillosis Study Group (JCPASG). Intravenous micafungin versus voriconazole for chronic pulmonary aspergillosis: a multicenter trial in Japan. J Infect. 2010;61:410-8. http://dx.doi.org/10.1016/j.jinf.2010.08.005

23. Cadranel J, Philippe B, Hennequin C, Bergeron A, Bergot E, Bourdin A, et al. Voriconazole for chronic pulmonary aspergillosis: a prospective multicenter trial. Eur J Clin Microbiol Infect Dis. 2012;31:3231-9. http://dx.doi.org/10.1007/s10096-012-1690-y

24. Ohba H, Miwa S, Shirai M, Kanai M, Eifuku T, Suda T, et al. Clinical characteristics and prognosis of chronic pulmonary aspergillosis. Respir Med. 2012;106:724-9. http://dx.doi.org/ 10.1016/j.rmed.2012.01.014

25. Jhun BW, Jeon K, Eom JS, Lee JH, Suh GY, Kwon OJ, et al. Clinical characteristics and treatment outcomes of chronic pulmonary aspergillosis. Med Mycol. 2013;51:811-7. http://dx.doi.org/10.3109/13693786.2013.806826

26. Kosmidis C, Denning DW. The clinical spectrum of pulmonary aspergillosis. Thorax. 2015;70:270-7. http://dx.doi.org/10.1136/ thoraxjnl-2014-206291

27. Pasqualotto AC, editor. Aspergillosis: from diagnosis to prevention. 1st ed. New York: Springer; 2010.

28. Tomlinson JR, Sahn SA. Aspergilloma in sarcoid and tuberculosis. Chest. 1987;92:505-8. http://dx.doi.org/10.1378/chest.92.3.505 
29. Camara B, Reymond E, Saint-Raymond C, Roth H, Brenier-Pinchart MP, Pinel C, et al.; Grenoble Aspergillus Committee. Characteristics and outcomes of chronic pulmonary aspergillosis: a retrospective analysis of a tertiary hospital registry. Clin Respir J. 2015;9:65-73. http://dx.doi.org/10.1111/crj.12105

30. Salzer HJ, Cornely OA. Awareness of predictors of mortality may help improve outcome in chronic pulmonary aspergillosis. Eur Respir J. 2017;49:2.

31. Salzer HJ, Heyckendorf J, Kalsdorf B, Rolling T, Lange C. Characterization of patients with chronic pulmonary aspergillosis according to the new ESCMID/ERS/ECMM and IDSA guidelines. Mycoses. 2017;60:136-42. http://dx.doi.org/10.1111/ myc. 12589

32. Farid S, Mohamed S, Devbhandari M, Kneale M, Richardson M, Soon SY, et al. Results of surgery for chronic pulmonary aspergillosis, optimal antifungal therapy and proposed high risk factors for recurrence - a national centre's experience. J Cardiothorac Surg. 2013;8:180. http://dx.doi.org/10.1186/ 1749-8090-8-180

33. Desai SR, Hedayati V, Patel K, Hansell DM. Chronic aspergillosis of the lungs: unravelling the terminology and radiology. Eur Radiol. 2015;25:3100-7. http://dx.doi.org/10.1007/s00330-015-3690-7

34. Franquet T, Müller NL, Giménez A, Guembe P, de La Torre J, Bagué S. Spectrum of pulmonary aspergillosis: histologic, clinical, and radiologic findings. Radiographics. 2001;21:825-37. http://dx.doi.org/10.1148/radiographics.21.4.g01j103825

35. Denning DW. Chronic forms of pulmonary aspergillosis. Clin Microbiol Infect. 2001;7(Suppl 2):25-31. http://dx.doi.org/10.1111/j.1469-0691.2001.tb00006.x

36. Greene R. The radiological spectrum of pulmonary aspergillosis. Med Mycol. 2005;43(Suppl 1):S147-54. http://dx.doi.org/10.1080/13693780500064771

37. Gadkowski LB, Stout JE. Cavitary pulmonary disease. Clin Microbiol Rev. 2008; 21:305-33. http://dx.doi.org/10.1128/ CMR.00060-07

38. Gotway MB, Dawn SK, Caoili EM, Reddy GP, Araoz PA, Webb WR. The radiologic spectrum of pulmonary aspergillus infections. J Comput Assist Tomogr. 2002;26:159-73. http://dx.doi.org/10.1097/00004728-200203000-00001

39. Martinez S, McAdams HP, Batchu CS. The many faces of pulmonary nontuberculous mycobacterial infection. AJR Am J Roentgenol. 2007;189:177-86. http://dx.doi.org/10.2214/ AJR.07.2074

40. Jude CM, Nayak NB, Patel MK, Deshmukh M, Batra P. Pulmonary coccidioidomycosis: pictorial review of chest radiographic and CT findings. Radiographics. 2014;34:912-25. http://dx.doi.org/10.1148/rg.344130134

41. Jeong YJ, Lee KS. Pulmonary tuberculosis: up-to-date imaging and management. AJR Am J Roentgenol. 2008;191:834-44. http://dx.doi.org/10.2214/AJR.07.3896

42. McAdams HP, Erasmus J, Winter JA. Radiologic manifestations of pulmonary tuberculosis. Radiol Clin North Am. 1995; 33:655-78.

43. Ko JM, Park HJ, Cho DG, Kim CH. CT differentiation of tuberculous and non-tuberculous pleural infection, with emphasis on pulmonary changes. Int J Tuberc Lung Dis. 2015;19:1361-8. http:// dx.doi.org/ 10.5588/ijtld.15.0092

44. Izumikawa K, Ohtsu Y, Kawabata M, Takaya H, Miyamoto A, Sakamoto S, et al. Clinical efficacy of micafungin for chronic pulmonary aspergillosis. Med Mycol. 2007;45:273-8. http://dx.doi.org/10.1080/13693780701278386

45. Roberts CM, Citron KM, Strickland B. Intrathoracic aspergilloma: role of CT in diagnosis and treatment. Radiology. 1987;165:123-8. http://dx.doi.org/10.1148/radiology.165.1.3628758

46. Muldoon EG, Sharman A, Page I, Bishop P, Denning DW. Aspergillus nodules; another presentation of chronic pulmonary aspergillosis. BMC Pulm Med 2016;16:123. http://dx.doi.org/ 10.1186/s12890-016-0276-3

47. Muniappan A, Tapias LF, Butala P, Wain JC, Wright CD, Donahue DM, et al. Surgical therapy of pulmonary aspergillomas: a 30-year North American experience. Ann Thorac Surg. 2014;97:432-8. http://dx.doi.org/10.1016/j.athoracsur.2013.10.050

48. Reischies F, Hoenigl M. The role of surgical debridement in different clinical manifestations of invasive aspergillosis. Mycoses. 2014;57(Suppl 2):1-14. http://dx.doi.org/10.1111/myc.12224

49. Page ID, Richardson MD, Denning DW. Comparison of six Aspergillus-specific IgG assays for the diagnosis of chronic pulmonary aspergillosis (CPA). J Infect. 2016;72:240-9. http://dx.doi.org/10.1016/j.jinf.2015.11.003

50. Dumollard C, Bailly S, Perriot S, Brenier-Pinchart MP, Saint-Raymond C, Camara B, et al. Prospective evaluation of a new aspergillus IgG enzyme immunoassay kit for diagnosis of chronic and allergic pulmonary aspergillosis. J Clin Microbiol. 2016;54:1236-42. http://dx.doi.org/10.1128/JCM.03261-15

51. Fujiuchi S, Fujita Y, Suzuki H, Doushita K, Kuroda H, Takahashi M, et al. Evaluation of a quantitative serological assay for diagnosing chronic pulmonary aspergillosis. J Clin Microbiol. 2016;54:1496-9. http://dx.doi.org/10.1128/JCM.01475-15

52. Kosmidis C, Powell G, Borrow R, Morris J, Alachkar H, Denning DW. Response to pneumococcal polysaccharide vaccination in patients with chronic and allergic aspergillosis. Vaccine. 2015;33:7271-5. http://dx.doi.org/10.1016/ j.vaccine.2015.10.114

53. Bongomin F, Harris C, Foden P, Kosmidis C, Denning DW. Innate and adaptive immune defects in chronic pulmonary aspergillosis. J Fungi (Basel). 2017;3:26. http://dx.doi.org/10.3390/jof3020026

54. Döffinger R, Harris C, Lear S, Newton P, Alachkar H, Dinakantha $\mathrm{S}$, et al. Impaired Th1 and Th17 immunity in chronic pulmonary aspergillosis. In: Proceedings of the 6th Advances against Aspergillosis. 6th Advances against Aspergillosis Conference; Feb 27-Mar 1, 2014; Madrid, Spain [cited 2018 May 23]. http://www.advancesagainstaspergillosis.org/2014/index.htm

55. Page ID, Richardson M, Denning DW. Antibody testing in aspergillosis - quo vadis? Med Mycol. 2015;53:417-39. http://dx.doi.org/10.1093/mmy/myv020

56. Kitasato Y, Tao Y, Hoshino T, Tachibana K, Inoshima N, Yoshida M, et al. Comparison of Aspergillus galactomannan antigen testing with a new cut-off index and Aspergillus precipitating antibody testing for the diagnosis of chronic pulmonary aspergillosis. Respirology. 2009;14:701-8. http://dx.doi.org/10.1111/j.1440-1843.2009.01548.x

57. Guitard J, Sendid B, Thorez S, Gits M, Hennequin C. Evaluation of a recombinant antigen-based enzyme immunoassay for the diagnosis of noninvasive aspergillosis. J Clin Microbiol. 2012;50:762-5. http://dx.doi.org/10.1128/JCM.01257-11

58. Baxter CG, Denning DW, Jones AM, Todd A, Moore CB, Richardson MD. Performance of two Aspergillus IgG EIA assays compared with the precipitin test in chronic and allergic aspergillosis. Clin Microbiol Infect. 2013;19:E197-204. http://dx.doi.org/10.1111/1469-0691.12133

59. Shin B, Koh WJ, Jeong BH, Yoo H, Park HY, Suh GY, et al. Serum galactomannan antigen test for the diagnosis of chronic pulmonary aspergillosis. J Infect. 2014;68:494-9. http://dx.doi.org/ 10.1016/j.jinf.2014.01.005

60. Oliva A, Flori P, Hennequin C, Dubus JC, Reynaud-Gaubert M, Charpin D, et al. Evaluation of the Aspergillus Western blot $\mathrm{IgG}$ kit for diagnosis of chronic aspergillosis. J Clin Microbiol. 2015;53:248-54. http://dx.doi.org/10.1128/JCM.02690-14

61. Page ID, Baxter C, Hennequin C, Richardson MD, van Hoeyveld E, van Toorenenbergen AW, et al. Receiver operating characteristic curve analysis of four Aspergillus-specific IgG assays for the diagnosis of chronic pulmonary aspergillosis. 
Diagn Microbiol Infect Dis. 2018;91:47-51. http://dx.doi.org/ 10.1016/j.diagmicrobio.2018.01.001

62. Page ID, Richardson MD, van Toorenenbergen A, Denning DW. Siemens Immulite Aspergillus-specific IgG assay for chronic pulmonary aspergillosis diagnosis. Med Mycol. 2018 [cited 2018 May 25]. https://doi.org/10.1093/mmy/myy024

63. Langridge PJ, Sheehan RL, Denning DW. Microbial yield from physiotherapy assisted sputum production in respiratory outpatients. BMC Pulm Med. 2016;6:23. http://dx.doi.org/10.1186/ s12890-016-0188-2

64. Nam HS, Jeon K, Um SW, Suh GY, Chung MP, Kim H, et al. Clinical characteristics and treatment outcomes of chronic necrotizing pulmonary aspergillosis: a review of 43 cases. Int J Infect Dis. 2010;14:e479-82. http://dx.doi.org/10.1016/ j.ijid.2009.07.011

65. Fraczek MG, Kirwan MB, Moore CB, Morris J, Denning DW, Richardson MD. Volume dependency for culture of fungi from respiratory secretions and increased sensitivity of Aspergillus quantitative PCR. Mycoses. 2014;57:69-78. http://dx.doi.org/ $10.1111 /$ myc. 12103

66. Camuset J, Nunes H, Dombret MC, Bergeron A, Henno P, Philippe B, et al. Treatment of chronic pulmonary aspergillosis by voriconazole in nonimmunocompromised patients. Chest. 2007;131:1435-41. http://dx.doi.org/10.1378/chest.06-2441

67. Cucchetto G, Cazzadori A, Conti M, Cascio GL, Braggio P, Concia E. Treatment of chronic pulmonary aspergillosis with voriconazole: review of a case series. Infection. 2015;43:277-86. http://dx.doi.org/10.1007/s15010-014-0711-4

68. Pashley CH, Fairs A, Morley JP, Tailor S, Agbetile J, Bafadhel M, et al. Routine processing procedures for isolating filamentous fungi from respiratory sputum samples may underestimate fungal prevalence. Med Mycol. 2012;50:433-8. http://dx.doi.org/10.3109/ 13693786.2011.615762

69. Howard SJ, Cerar D, Anderson MJ, Albarrag A, Fisher MC, Pasqualotto AC, et al. Frequency and evolution of azole resistance in Aspergillus fumigatus associated with treatment failure. Emerg Infect Dis. 2009;15:1068-76. http://dx.doi.org/10.3201/ eid1507.090043

70. Izumikawa K, Yamamoto Y, Mihara T, Takazono T, Morinaga Y, Kurihara S, et al. Bronchoalveolar lavage galactomannan for the diagnosis of chronic pulmonary aspergillosis. Med Mycol. 2012;50:811-7. http://dx.doi.org/10.3109/13693786.2012.682228

71. Fayemiwo S, Moore CB, Foden P, Denning DW, Richardson MD. Comparative performance of Aspergillus galactomannan ELISA and PCR in sputum from patients with ABPA and CPA.

J Microbiol Methods. 2017;140:32-9. http://dx.doi.org/10.1016/ j.mimet.2017.06.016

72. Prattes J, Flick H, Prüller F, Koidl C, Raggam RB, Palfner M, et al. Novel tests for diagnosis of invasive aspergillosis in patients with underlying respiratory diseases. Am J Respir Crit Care Med. 2014;190:922-9. http://dx.doi.org/10.1164/rccm.201407-1275OC

73. Eigl S, Prattes J, Lackner M, Willinger B, Spiess B, Reinwald M, et al. Multicenter evaluation of a lateral-flow device test for diagnosing invasive pulmonary aspergillosis in ICU patients. Crit Care. 2015;9:178. http://dx.doi.org/10.1186/s13054-015-0905-x

74. Godet C, Alastruey-Izquierdo A, Flick H, Hennequin C, Mikilps-Mikgelbs R, Munteanu O, et al.; CPAnet. A CPAnet consensus statement on research priorities for chronic pulmonary aspergillosis: a neglected fungal infection that requires attention. J Antimicrob Chemother. 2018;73:280-6. http://dx.doi.org/10.1093/ $\mathrm{jac} / \mathrm{dkx} 390$

Address for correspondence: David W. Denning, National Aspergillosis Centre, University Hospital of South Manchester, Southmoor Rd, Manchester M23 9LT, UK; email: ddenning@manchester.ac.uk

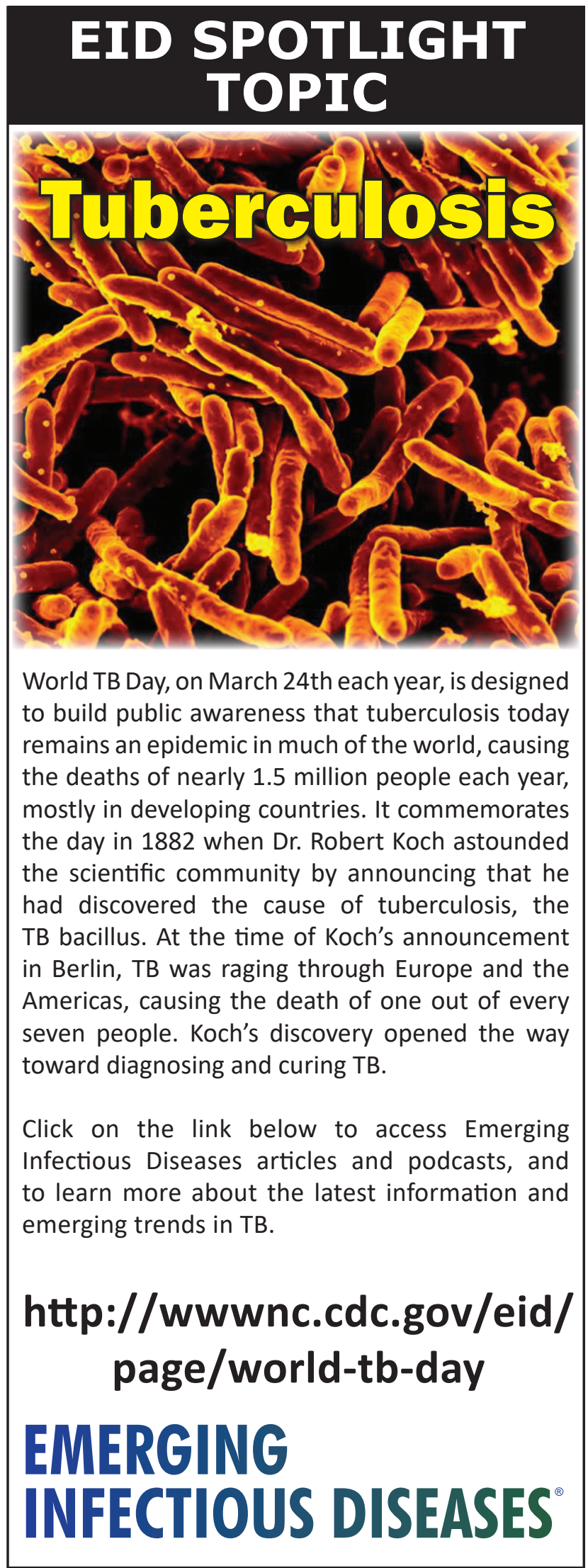

